\title{
Toward a novel tourism experience: simulating ancient Egyptian lifestyle through tourism and hospitality services
}

\author{
Abuelkassem A. A. Mohammad ${ }^{1} \quad$ Haitham T. A. Sotohy ${ }^{2} \quad$ Salama A. M. Ammar $^{2}$ \\ ${ }^{1}$ Faculty of Tourism and Hotels-Minia University, ${ }^{2}$ The Higher Institute for Tourism and Hotels \\ (EGOTH)-Luxor.
}

\begin{abstract}
This study aims to determine the applicability of a suggested tourism experience that enable international tourists to simulate the lifestyle of ancient Egyptians in Luxor. It also aims to understand the attitudes of both tourists and service providers-i.e. tourism and hospitality enterprises-toward this experience. The study adopted a qualitative approach and used semistructured interview as an instrument for collecting primary data. A total of 118 interviews were conducted with both tourists (73) and service providers (45) in Luxor. Participants were selected using convenience sampling technique due to accessibility issues. All interviews were transcribed and then content analysis was used as a technique for analyzing the gathered data. The results indicated that the suggested tourism experience is applicable by service providers and acceptable by tourists. Out of the various proposed simulated services, the results revealed some specific tourism and hospitality services to be included in the proposed experience such as dining facilities and recreation activities. Another important finding of the study showed that both tourists and service providers have positive attitudes toward the introduced tourism experience.
\end{abstract}

Keywords: Novel Tourism, Simulating Lifestyle, Ancient Egypt, Tourism, Hospitality, Luxor.

\section{Introduction:}

Tourists always seek new experiences and original products or services (Lepp and Gibson, 2008). In fact, experiencing local culture of host destinations that tourists cannot experience at their home country was reported as a primary motive for international travel that affects the choice of a destinations (Ariffin and Maghzi, 2012; Ariffin and Yahaya, 2013). Therefore, tourist destinations always aspire to provide unique experience through newly developed tourism and hospitality services that attract novelty seeking travelers (Chang, Wall and Chu, 2006) such as tea tourism in china (Cheng, Xu, Zhang, and Zhang, 2010) or wine tourism in Europe (Hal et al., 2009). Yet relatively few studies have thoroughly investigated this issue (Chandralal and Valenzuela, 2013).

Egypt, as a tourist destination, has many resources and attraction that support various types of tourism and enable the development and provision of new tourism experiences with various original products and services (Abd-El-Jalil, 2010). Therefore, the current study aims to explore the expectations and attitudes of both demand side (tourists) and supply side (tourism and hospitality enterprises including: hotels; restaurants; cafés; travel agents; museums; transportation; etc.) toward a suggested tourism experience that enable tourist to simulate the lifestyle of ancient Egyptian in Luxor through some suggested tourism and hospitality services and products. The ancient Egyptian lifestyle is applied in some tourist destinations in Egypt than Luxor, in a number of archeological sites such activities were applied like using animals in transportation, the current study aims to apply a complete example of ancient Egyptian lifestyle in its original places. Luxor was chosen as it is the most important touristic destination in Egypt, it is the place of ancient Thebes, the capital of Egypt during the empire era. The significance of doing that is to provide some insights that enable a better understanding of both customers' and services providers' attitudes toward providing nontraditional tourism and hospitality services. 


\section{Literature review \\ Tourism experience and novelty}

Tourism experience refers to the integration of certain tourism products and services encompassed in a package and provided in tourism destination (Chandralal and Valenzuela, 2013). Thus, tourism experience involves a wide range of tourism products and services, transportation, accommodation, food and beverage, sightseeing, recreation and entertainment (Cheng and Lu, 2013). Lee et al. (2009) explained that local culture of destinations, including traditions, gastronomy and leisure activities is a principal attraction for tourist. They further added that tourists tend to purchase cultural products to have a unique experience that is not available in their country of origin.

Cheng and $\mathrm{Lu}$ (2013) explained that novelty in tourism and hoapitality settings refers to the percieved orginiality or uniqueness of a vaction destination including historical landmarks, cultural atmosphere loacl residents, etc. Novel tourism experinces fulfill several purposes for tourists such as thrill, change from routine, surprise and alleviation of boredom. The study of Chandralal and Valenzuela (2013) confirmed that perceived novelty of the tourism experience, in terms of: staying in accommodation facilities different than typical hotels; getting exposed to different culture and lifestyle; trying nontraditional food, is a key factor of creating memorable tourism experience for travelers which in turn will influence their future travel or re-visit decisions.

\section{Attitudes toward new services}

Attitudes refers to the mental state that is developed based on experience and influence individuals' responses or behaviors toward relevant situations or objects related to this state. That is, attitude is the tendency to positively or negatively act with regard to objects (Ajzen, 2005). According to Casaló et al. (2015), attitude is a three-dimensional construct that includes: (1) cognitive or mental attitude; (2) affective or emotional attitudes; (3) conative or behavioral attitudes. Tourist attitudes are reported to be a leading predictor of behavioral intentions and actual behaviors (Williams et al., 2011). That is, positive attitudes toward a new tourism experiences can encourage purchase intentions or engagement with such new experience and vice versa. Consequently, tourism and hospitality marketers tend to regularly explore tourist attitudes toward any intended new service/product development or provision (Reid and Bojanic, 2009).

\section{Lifestyle of ancient Egyptians}

The daily life scenes in new Kingdom Theban tombs represent an ideal everyday life activity (Hartwig, 2004). These scenes illustrate the clothing, the conduct of professions and the leisure activities of actual people (Brier and Hobbs, 2008). The scenes in Luxor tombs refer here to the nobles' lifestyle; other categories of the society are shown in tomb scenes in other places in Egypt. As for recreation, the most common recreational activities were banquets, hunting, fishing and sport (plate 1) (Brier and Hobbs, 2008). Desert hunting was a favorite activity. Another ancient Egyptian amusement included sailing to enjoy the cool breeze of the Nile (Brier and Hobbs, 2008). Music provided another favored entertainment. Scenes on tomb walls depict an orchestra, with dancers swaying to its rhythms. Flutes were blown from their ends rather than their sides unlike the modern flute. Mandolins were held vertically like guitars; Dancers' rhythmic clapping added sounds to a performance. Only women danced at banquets (plate 3) (Brier and Hobbs, 2008). Games ranged from sedate board types to more physical ones such as wrestling (Brier and Hobbs, 2008).

Ancient Egyptians used the term "bread and beer" to describe their basic meals (Brier and Hobbs, 2008). Common people dined infrequently on meat but depended mainly on fish and wild 
fowl for their protein. Vegetables and fruits also formed a large part of the diet of the ancient Egyptians including figs, grapes, Melons, date and palms (Brier and Hobbs, 2008). When it comes to beverage, the wealthy preferred the wine while beer was considered the beverage of working people (plate 4) (Brier and Hobbs, 2008).

The kilt was the most common clothing for Egyptian males, this is a rectangular piece of fabric that was wrapped tightly around the waist and tied in the front with cords or belted. The most common woman's attire was a dress held up by shoulder straps, a long narrow dress that began at the ankles and rose to just under the breasts. (Brier and Hobbs, 2008). Sandals were known, but they usually use it in special occasions. (Montet, 1964). At banquets, both males and females wore the same sort of fine dress, address similar to the saris still worn throughout India nowadays (Brier and Hobbs, 2008). Wigs were of special importance during the celebration of feasts (Montet, 1964). Other dressing examples like tunics and triangular loincloths were noted in the New Kingdom tomb scenes (Watson, 1987).

Many evidences refer to the notion that the ancient Egyptians travelled a lot within their country and outside. The most famous way of transportation was the river (Montet, 1964). The Pilgrimage to Abydos was a very famous travel activity all over the Egyptian history (Manniche, 1987). Outside Egypt, queen Hatshepsut of the eighteenth dynasty organized a large trading expedition to the land of Punt (possibly modern Somalia). The voyage is depicted on the walls of her funerary temple at Deir el-Bahri (plate 2) (Montet, 1964; Partridge, 2010).

\section{A day in ancient Luxor during the new kingdom period}

A picture of life in the Theban area during the New Kingdom can be obtained. On the East Bank there is a relatively large settlement, spreading from the area around the temples at Karnak down to the Luxor Temple (Strudwick and Strudwick, 1999). The ordinary people lived in small houses on both sides of the avenue linking Karnak and Luxor temple. Through the available sources of the daily life in Thebes in the New Kingdom period, a model of a day in the life of some ancient Egyptians could be made as follow:

Early morning: The ancient Egyptians used to wash up at early morning before and after having their breakfast (Montet, 1946). The male put on simple kilt and women put on dresses.

Breakfast: The Ancient Egyptians eat seated around a small table. The father after washing up was presented bread, beer, and pie. The mother takes her breakfast while making her morning coiffure (Montet, 1946)

Work

Agriculture was the basic occupation in Egypt in the new kingdom period. The main crop was grain. The farmers work in their fields and used animals like cows in plowing and cultivation (Montet, 1946). The work began at early morning and ends at evening.

A workman of Deir El Medina began his day early and takes the way to the valley from the Deir El Medina. The way to work was extremely spectacular; it was on the hillside led from the village up on to a pathway running along the cliffs towards Deir el-Bahari. Another rising pathway led up on to the Valley of the Kings (Strudwick and Strudwick, 1999). The working day consisted of two spells of work which lasted four hours each, and a break for lunch between. In the attendance record a working day for a worker is in black and absence is in red (Strudwick and Strudwick, 1999).

Evening: The men return from work at sunset, and they must find their house lighted with lambs (museums have many examples of oil lambs). The main meal should include meat (chicken) and vegetables and fruit. Then they spend one or two hours and sleep early to wake up early at dawn (Montet, 1946) 
Religious activities: Egyptian lives were so connected with gods; they felt no need to special times for praying together. Only on rare festival days might groups congregate outside a temple to witness a performance of holy rites (Brier and Hobbs, 2008). The people celebrated the main holidays connected to the cult of Amun-re in Thebes. At the festival days it appears that the people have taken time off brewing beer for consumption at the eminent festival. Some stela in the houses refers to the fact that they had special worship inside (Strudwick and Strudwick, 1999)

\section{Methodology}

This study adopted a qualitative approach and used semi-structured interviewee as a tool for collecting primary data. The interview includes four major sections. Section one was an introduction about the research subject. Section two included three questions and aimed to determine the applicability of the proposed tourism experience as well as the services, products or facilities that can be included in this experience. Section three involved five questions and was about the attitudes of the participants toward the suggested tourism experience. Lastly, section four included one question that aimed at gathering any additional comments or suggestions made by the interviewees. To ensure the validity and reliability of the instrument, the interview questions were externally audited by a panel of three academics experts who reviewed, edited and confirmed the validity and reliability of the interview questions.

The interviews were conducted among two stakeholder categories to involve both the demand side (i.e. tourists) and the supply side represented by providers of tourism and hospitality services (e.g. hotels, restaurants, travel agents, museums, temples, transportation providers, etc.). The participants included a total of 73 international tourists from various countries representing the demand side as well as a total of 45 tourism and hospitality enterprises ( 21 hotels and restaurants and 24 travel agents, tour operators and temples) to present the supply viewpoint. All interviewees were anonymously referred to in this study to assure the confidentiality of participants' personal information. Interviews were conducted by the researchers who directly conducted face-to-face interviews. Collected data was transcribed and set for analysis and content analysis technique was adopted to analyze the collected data.

\section{Results and discussion}

\section{Applicability of the proposed tourism experience}

This section involved three questions and aimed to determine whether the suggested tourism experience is feasible and applicable or not. First, tourists were asked if they are interested in trying new tourism services or products. The results showed that the majority of the respondents (73.5\%) reported a positive opinion and confirmed that they are really interested in experiencing new tourism services. However, a significant percentage reported that they are either less interested or not interested at all $(26.5 \%)$ in trying new tourism services. For instance, one the tourists stated that "Yes, I enjoy new experiences and I love sightseeing and ancient monuments". In addition, tourism and hospitality service providers were asked if they are interested in providing new tourism services. The largest percentage of both tourism and hospitality enterprises (79\%, 71\%; respectively) declared that they always seek to provide new services and products as long as tourists are interested in these new services. On the other hand, some enterprises revealed that they prefer to provide traditional services and occasionally they tend to provide new services. Among participants' comments, one travel agent explained that "any successful tourism enterprise always provide new products to distinguish itself from others and to attract more tourists" 


\section{Simulated tourism and hospitality services}

This part aims to explore the expectations of both tourists and service providers with regard to the simulated tourism and hospitality services that they desire to be included in the suggested novel tourism experience. The findings showed that respondents were interested in experiencing several simulated tourism and hospitality services as summarized in Table 1.

Simulated dining service was the most desired feature with the majority of both tourists (83\%.5) and service providers $(73.3 \%)$ voting for it to be provided in the suggested tourism experience. This includes themed dining restaurants with ancient Egyptian décor, music, uniform and serving methods. On this note, one tourist argued that "This could be interesting, but do not forget the beer jars!". Similarly, a significant percentage of tourists $(87.5 \%)$ and services providers $(71 \%)$ endorsed the availability of ancient-like recreation activities such as music concerts or Nile sailing. In addition, simulated or themed accommodation facilities were also highly desired by most of the interviewed tourists $(78 \%)$ and service providers $(71 \%)$. Such facilities can include pharaonic-style houses or lodging facilities equipped with ancient-style furniture and linen. One travel agent said that "I think that tourist would like to join simulated recreation activities as it reflects the spirit and the atmosphere of place".

Table 1: Simulated tourism and hospitality services ( $n=73$ tourists; 45 service providers)

\begin{tabular}{|l|c|c|c|c|}
\hline \multirow{2}{*}{$\begin{array}{l}\text { Simulated tourism and } \\
\text { hospitality services }\end{array}$} & \multicolumn{2}{|l|}{ Tourists } & \multicolumn{2}{l|}{ Tourism and hospitality enterprises } \\
\cline { 2 - 5 } & Desired & Not desired & Desired & Not desired \\
\hline Dining services & $61(83.5 \%)$ & $12(16.5 \%)$ & $33(73.3 \%)$ & $16(26.7 \%)$ \\
\hline Recreation activities & $64(87.5 \%)$ & $9(12.5)$ & $29(71 \%)$ & $16(29 \%)$ \\
\hline Accommodation facilities & $57(78 \%)$ & $16(22 \%)$ & $23(51 \%)$ & $22(49 \%)$ \\
\hline Transportation services & $41(56.2 \%)$ & $32(43.8 \%)$ & $18(40 \%)$ & $27(60 \%)$ \\
\hline
\end{tabular}

Moreover, simulated transportation activities were also expected to be included in this tourism experience where several tourists $(56.2 \%)$ and services providers $(40 \%)$ believed that it is a good idea to offer themed means of transportation including carts and Nile boats in addition to using animals for transportations such as camels, horses and donkeys. Among the comments of the participants, one travel agent explained that "from my personal experience, I think tourists will be interested in commuting by primitive means such as horses, donkeys, carts and Nile boats". Also, one tourist said that "it is an exciting idea to travel by a bus or a train that has ancient theme or atmosphere". Lastly, the results also showed that a fewer number of tourists $(28.7 \%)$ and services providers $(24.4 \%)$ suggested some imitated religious ceremonies to be added to the introduced tourism package, such as offering food and thanks to ancient gods. A tourist mentioned that "I would love to engage in such spiritual rituals as long as they are historically right".

Additionally, respondents were asked about the appropriate duration for the proposed tourism experience. The largest percentage of the interviewees $(65 \%$, i.e. 77 participants) agreed that one day is an adequate length for experiencing simulated tourism and hospitality services. Other participants thought that either half a day $(19.5 \%)$ or more than one day $(15.5 \%)$ is good enough

for trying such services. For example, one of the tourists said that "I think one-day and half-day options are enough" and another one stated that "I am an active person, full day sounds good to me".

\section{Attitudes toward the proposed tourism experience}

This section aimed to determine the attitudes of both tourists and service providers toward the suggested tourism experience. Based on the three dimensions of attitude (cognitive, affective and conative), the results are summarized in Table 2 and discussed below.

First, interviewees were asked how they rationally think about a tourism experience that enable them to simulate the lifestyle of the ancient Egyptians. A reasonable number of both tourists 
$(80.8 \%)$ and tourism and hospitality enterprises $(71 \%)$ have agreed that such experience is a good idea or a reasonable decision. One of the interviewees reported that "it is a good idea as it represents something original". Some interviewees (64.3\% tourists and \% 64.5 service providers) also believed that this tourism experience will add value to the overall tourism trip. One of the interviewed travel agents revealed that "of course including these imitated services in tour program will be valuable as tourists as they always look for new adventures and untraditional experiences". Nevertheless, some respondents (14 tourists and 11 service providers) reported a neutral stand and disputed that they were uncertain about their opinion regarding the proposed tourism package.

Second, in order to explore the emotional responses toward ancient-style tourism and hospitality services, participants were asked how they feel bout engaging in such tourism experience. Approximately $83.5 \%$ of the tourists and $77.7 \%$ of the service providers reported a positive sentimental reaction in terms of excitement, curiosity and interest. Among the positive reactions, one tourist said that "this sounds interesting and I am intrigued to try something like that". However, some interviewees (13 tourists and 11 service providers) expressed a negative emotional reaction toward experiencing lifestyle of ancient Egyptians through customized tourism and hospitality services and consider it be less attractive or fake experience. For example, on tourist argued that "I don't think we can actually imitate the way that ancient Egyptians used to live through artificial or fake facilities".

Third, respondents were asked about the behavioral attitudes in terms of intentions to buy the proposed tourism experience or willingness to engage in such activities. The responses of the interviewees showed that about $78 \%$ of the tourists had tendencies to buy the proposed simulated services if they are available and they were willing to engage in any recreation activities that imitate ancient Egyptians way of life. Similarly, a large percentage of the tourism and hospitality service providers $(66.7 \% \%)$ reported that a reasonable number of tourists may be willing to try some services or products that replicate the daily life of ancient Egyptians. Among participants comments, one travel agent stated that "from my experience as a travel agent, I think many tourists will pay to participate in some of the services or activities that you are suggesting".

Table 2: Attitudes toward the suggested experience ( $\mathrm{n}=73$ tourists; 45 service providers)

\begin{tabular}{|c|c|c|}
\hline Attitudes & Tourists & Tourism and hospitality enterprises \\
\hline \multicolumn{3}{|l|}{ Cognitive attitude } \\
\hline Good idea or reasonable decision & $59(80.8 \%)$ & $34(75.5 \%)$ \\
\hline Add value to trip & $53(64.3 \%)$ & $29(64.5 \%)$ \\
\hline Not sure or undecided & $14(19.2 \%)$ & $11(24.5 \%)$ \\
\hline \multicolumn{3}{|l|}{ Affective attitude } \\
\hline Sounds interesting & $61(83.5 \%)$ & $35(77.7 \%)$ \\
\hline Feeling excited & $47(24.4 \%)$ & $26(57.7 \%)$ \\
\hline Less attractive or fake & $13(17.8 \%)$ & $11(24.5 \%)$ \\
\hline Neutral or do not know & $11(15 \%)$ & $8(17.7 \%)$ \\
\hline \multicolumn{3}{|l|}{ Conative or behavioral } \\
\hline Willingness to engage in this experience & $57(78 \%)$ & $30(66.7 \%)$ \\
\hline Good idea or reasonable decision & $59(80.8 \%)$ & $34(75.5 \%)$ \\
\hline
\end{tabular}

Lastly, tourists were asked about the reasons or purposes that may encourage them to get involved in this tourism experience. The findings showed the majority of interviewees $(61.6 \%$ of tourists and $60 \%$ of service providers) reported that the main reason for engaging in this tourism experience is for entertainment and recreation purposes. Other interviewees (19\% of tourists and $26.6 \%$ of service providers) argued that some people may be interested in this tourism experience to learn about the culture of ancient Egyptians, particularly about the extraordinary 
abilities of ancient Egyptians that enabled them to build these enormous landmarks and monuments. For example, a tour leader said that "most tourists will be mainly interested in these imitated services to have fun and enjoy themselves". Also, one tourist explained that "I think that reliving the lifestyle of ancient Egyptian can help to understand how these people managed to build a great civilization".

Table 3: Purposes for engaging in the experience ( $\mathrm{n}=73$ tourists; 45 service providers)

\begin{tabular}{|l|c|c|}
\hline Purposes for engaging in the proposed experience & Tourists & Tourism and hospitality enterprises \\
\hline Entertainment and recreation & $45(61.6 \%)$ & $27(60 \%)$ \\
\hline Learning about ancient culture & $14(19 \%)$ & $12(26.6 \%)$ \\
\hline
\end{tabular}

\section{Additional comments}

In the last part of the interview, respondents were asked if they have any additional comments of suggestions to add. The results indicated some suggestions. First, some tourists (about 12\%) proposed setting fair or affordable prices for this tourism experience. Other participants (nearly 6\%) suggested providing these simulated services in their actual places and local people should be incorporated as part of this experience to add more authenticity.

\section{Conclusion and recommendations}

This study presents some important findings. Providing simulated tourism and hospitality services that imitate the lifestyle of Egyptians during ancient ages is an applicable and feasible tourism experience that can draw the attention of many international tourists, particularly those who are interested in history and monuments sightseeing. There are many imitated services and products that can be provided to tourists, such as: entertainment and recreation activities that imitate the ancient Egyptians; ancient-style accommodation and dining services; primitive transportation such as carts or animals. The study also showed that both tourists and tourism and hospitality enterprises have appositive attitudes toward theses type of tourism experiences which can serve many purposes for interested tourists, such as entertainment and learning.

Based on its findings, this study provides some recommendations. First, tourism and hospitality enterprises are encouraged to develop and provide various services and products that imitate the lifestyle of ancient Egyptians as a significant percentage of tourists are interested in these services. Also, service providers (e.g. hotels; café, transportation, etc.) need to collaborate with each other to provide an integrated tourism package or experience that involves several simulated tourism and hospitality services. It is also recommended that the simulated services package to be a part of the tourism program for half day or one full day and should be provided at affordable or reasonable prices. Tourism and hospitality service providers are advised to make the simulated services historically accurate and as original and authentic as possible to attract novelty seeking tourists. Last but not least, service providers are recommended to create and present these imitated services as entertainment and recreation programs to enhance the overall tourism trip. 


\section{Plates}

Plate 1: Hunting in marshes in a scene from the tomb of nakht TT52 (Hartwig, 2004)

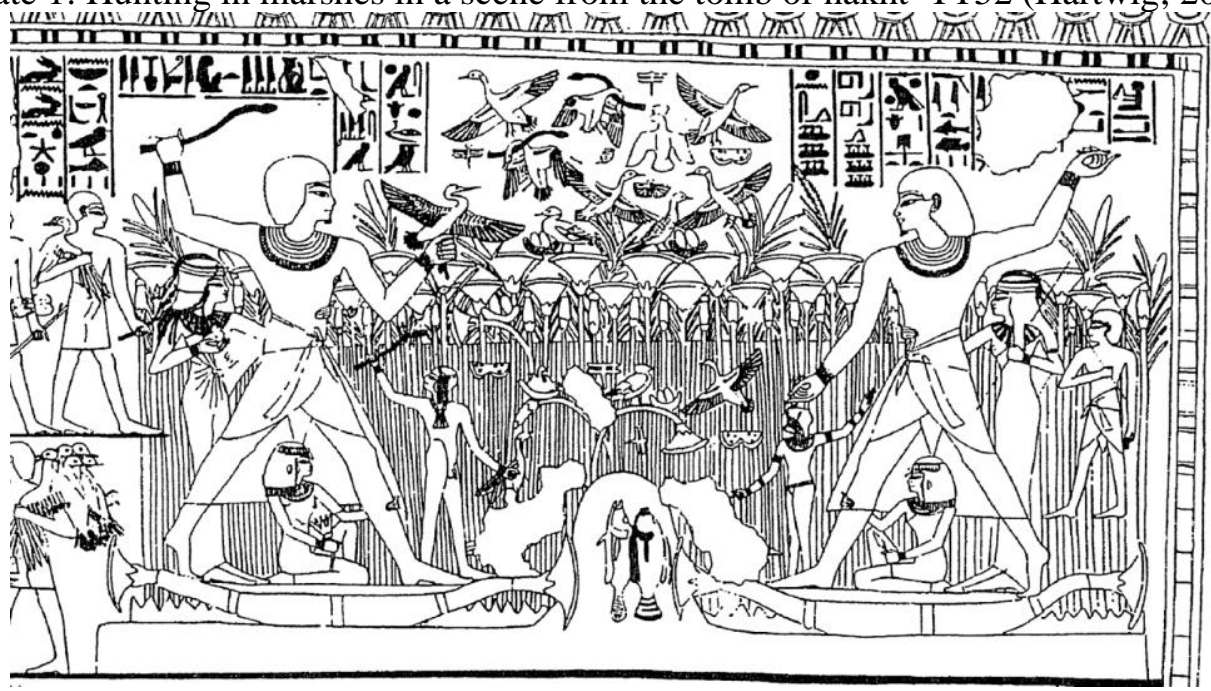

Plate 2: Ships as a way for transportation as represented in Hatshepsuit temple at Deir El Bahari, (Brier and Hobbs, 2008)

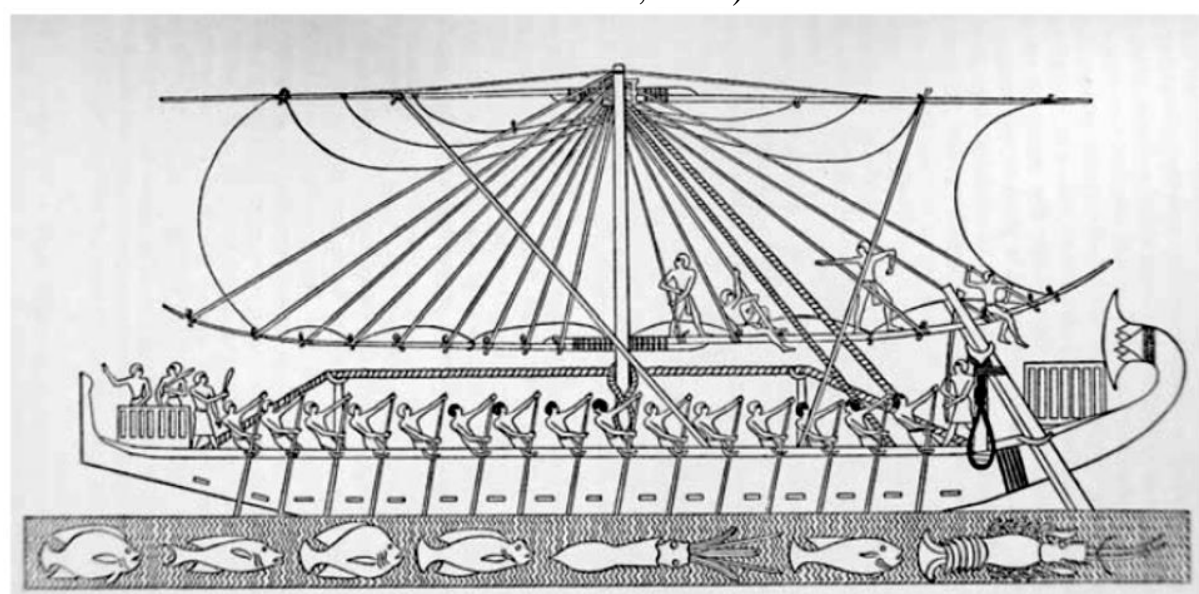

Plate (3) Playing music in a scene from the tomb of nakht TT52 (Hartwig, 2004)

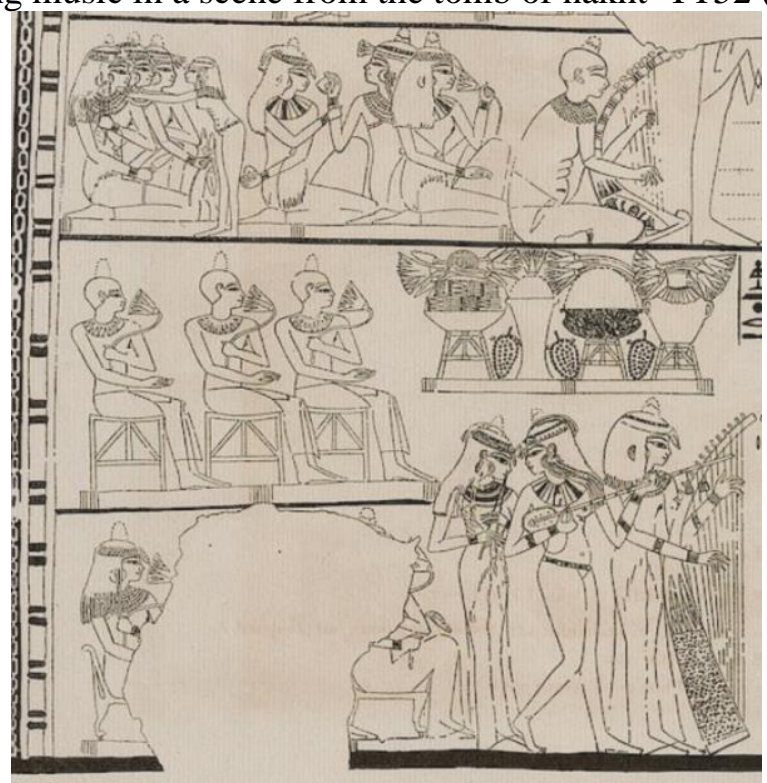


Plate (4) Scenes of collecting grapes and making wine (Brier and Hobbs, 2008)

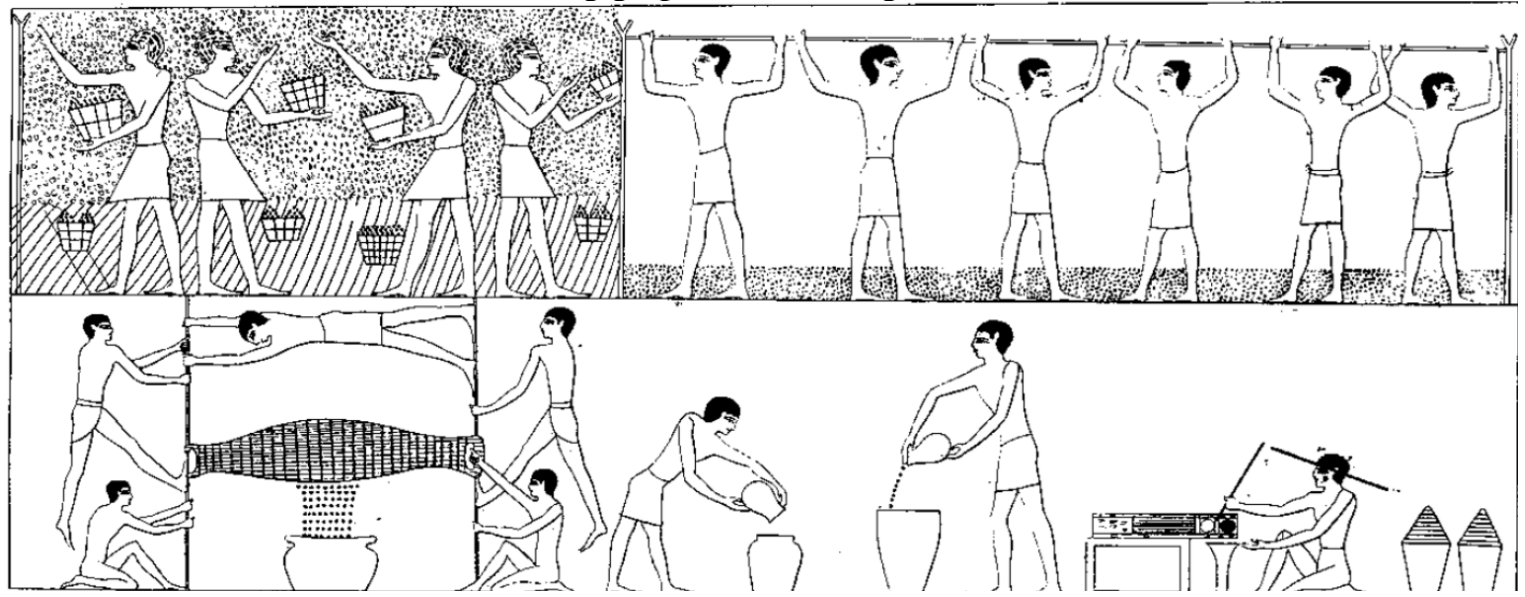

\section{References}

Abd-El-Jalil, S. J. (2009). Images of Egypt in United Kingdom tour operators' brochures. Tourismos: An International Multidisciplinary Journal of Tourism, 5(2), 179-191

Ajzen, I. (2005). Attitudes, personality, and behavior. McGraw-Hill Education: United Kingdom.

Ariffin, A. A. M., and Maghzi, A. (2012). A preliminary study on customer expectations of hotel hospitality: Influences of personal and hotel factors. International Journal of Hospitality Management, 31(1), 191-198. https://doi.org/10.1016/j.ijhm.2011.04.012.

Ariffin, A. A. M., and Yahaya, M. F. (2013). The relationship between airport image, national identity and passengers delight: A case study of the Malaysian low cost carrier terminal (LCCT). Journal of Air Transport Management, 31, 33-36. https://doi.org/10.1016/j.jairtraman.2013.02.005.

Brier, B. and Hobbs H. (2008). Daily life of the Ancient Egyptians. $2^{\text {nd }}$ editon. London, Greenwood.

Casaló, L. V., Flavián, C., Guinalíu, M., and Ekinci, Y. (2015). Do online hotel rating schemes influence booking behaviors? International Journal of Hospitality Management, 49, 28-36. https://doi.org/10.1016/j.ijhm.2015.05.005

Chang, J., Wall, G., and Chu, S. T. T. (2006). Novelty seeking at aboriginal attractions. Annals of Tourism Research, 33(3), 729-747.

Chandralal, L., and Valenzuela, F.-R. (2013). Exploring Memorable Tourism Experiences: Antecedents and Behavioural Outcomes. Journal of Economics, Business and Management, 1(2), 177-181. https://doi.org/10.7763/joebm.

Cheng, T. M., and Lu, C. C. (2013). Destination image, novelty, hedonics, perceived value, and revisiting behavioral intention for island tourism. Asia Pacific Journal of Tourism Research, 18(7), 766-783.

Cheng, S., Xu, F., Zhang, J., and Zhang, Y. (2010). Tourists' attitudes toward tea tourism: A case study in Xinyang, China. Journal of Travel and Tourism Marketing, 27(2), 211-220.

Hall, C. M., Sharples, L., Cambourne, B., and Macionis, N. (2009). Wine tourism around the world. Routledge.

Hartwig, M. K. (2004). Tomb Painting and Identity in Ancient Thebes, 1419-1372 BCE. Monumenta Aegyptiaca X. Brepols Publishers n.v., Turnhout, Belgium

Lee, Y., Kim, S., Seock, Y. K., and Cho, Y. (2009). Tourists' attitudes towards textiles and apparel-related cultural products: A cross-cultural marketing study. Tourism Management, 30(5), 724-732. https://doi.org/10.1016/j.tourman.2008.10.007

Lepp, A., and Gibson, H. (2008). Sensation seeking and tourism: Tourist role, perception of risk 
and destination choice. Tourism Management, 29(4), 740-750.

Montet, P. (1946). La vie quotidienne en Egypte au temps de Rameses 1300-1100, Paris, Librairie Hachette.

Partridge, R. B. (2010). Transport in Ancient Egypt, In Alan B. Lloyd (ed.) A companion to Ancient Egypt, Chichester, United Kingdom, Blackwell.370-389.

Reid, R. D., and Bojanic, D. C. (2009). Hospitality marketing management. John Wiley and Sons.

Serjeant, W. (1984). Attitudes. Journal of the Society of Archivists, 7(6), 343-347. https://doi.org/10.1080/00379818409514251.

Watson, Philip J. (1987) Costume of Ancient Egypt. New York: Chelsea House.

Williams, P., Khan, M. S., Ashill, N. J., and Naumann, E. (2011). Customer attitudes of stayers and defectors in B2B services: Are they really different? Industrial Marketing Management, 40(5), 805-815. https://doi.org/10.1016/j.indmarman.2010.12.001 